\title{
Research Paper: \\ Antioxidant and Hypolipidemic Effects of Methanolic Root Extract of Chromolaena odorata in Alloxan-induced Diabetic Rats
}

\author{
Oluyemisi Omotayo Omonije ${ }^{1^{*}}$ Q, Abubakar Ndaman Saidu ${ }^{1}$ Q, Hadiza Lami Muhammad ${ }^{1}$
}

1. Department of Biochemistry, Federal University of Technology, Minna, Nigeria.

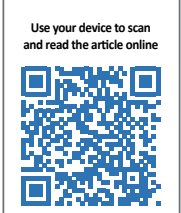

How to cite this paper Omotayo Omonije O, Ndaman Saidu A, Lami Muhammad H. Antioxidant and Hypolipidemic Effects of Methanolic Root Extract of Chromolaena odorata in Alloxan-induced Diabetic Rats. Iranian Journal of Toxicology. 2020; 14(2):63-70. http://dx.doi.org/10.32598/ijt.14.2.612

http://dx.doi.org/10.32598/ijt.14.2.612

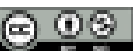

Article info:

Received: 21 Jul 2019

Accepted: 27 January 2020

Online Published: 01 Apr 2020

* Corresponding author:

Oluyemisi Omonije, PhD.

Address: Department of Biochemistry,

Federal University of Technology,

Minna, Nigeria

E-mail: oluyemisi.pg915840@

st.futminna.edu.ng

\section{ABSTRACT}

Background: Chromolaena odorata (C. odorata) is a medicinal plant with hypoglycemic effect known in traditional medicine. The present study investigated the in vitro antioxidant and in vivo anti-hyperglycemic effect of the methanol root extract of $C$. odorata in rats.

Methods: Phytochemical compositions were evaluated, using standard procedures while the antioxidant activities were examined, using 1,1-Diphenyl-2-Picrylhydrazyl (DPPH) Free Radical Scavenging and Ferric Reducing Power (FRAP) assays. Twenty albino rats were administered $120 \mathrm{mg} / \mathrm{kg}$ of body weight (bw) alloxan and were divided into four groups of five animals each. Groups A to D were treated with $2 \mathrm{ml} / \mathrm{kg}$ of normal saline, $300 \mathrm{mg} / \mathrm{kg}, 500$ $\mathrm{mg} / \mathrm{kg}$ bw extract and $5 \mathrm{mg} / \mathrm{kg}$ bw glibenclamide, respectively, through oral route for 14 days. Blood samples were collected and prepared for the analysis of serum lipids profile.

Results: The extract contained tannins $(54.76 \pm 4.08 \mathrm{mg} / 100 \mathrm{~g})$, saponins $(322.78 \pm 17.35 \mathrm{mg} / 100$ g), glycosides, alkaloids ( $74.34 \pm 6.08 \mathrm{mg} / 100 \mathrm{~g})$, flavonoids $(79.63 \pm 4.55 \mathrm{mg} / 100 \mathrm{~g})$, phenols $(154.32 \pm 11.21 \mathrm{mg} / 100 \mathrm{~g})$, glycosides, steroids and reducing sugar. The extract promoted the inhibition of DPPH radicals with IC50 values of $191.68 \pm 1.68 \mu \mathrm{g} / \mathrm{mL}$. In comparison with the untreated controls, total cholesterol, Low Density Lipoprotein (LDL)-cholesterol and triglycerides were significantly reduced $(\mathrm{P}<0.05)$ following treatment with $C$. odorata extract while High Density Lipoprotein (HDL)-cholesterol, was significantly increased.

Conclusion: The $C$. odorata extract exhibited antioxidant and hypolipidemic effects in alloxan-induced diabetic rat, thus could be considered as a natural product in the management of dyslipidemia secondary to diabetes.

Keywords: Antioxidants; C. odorata extract; Diabetes mellitus; Hypolipidemia; Blood lipid profile

\section{Introduction}

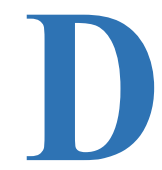

iabetes is a condition where the pancreas produces insufficient amount of insulin or when the body is unable to efficiently recognize the insulin or both [1]. Although some pathogeneses of diabetic complications are not well understood, many biochemical path- ways associated with the hyperglycemia have been implicated [2]. Besides hyperglycaemia, hyperlipidaemia is also considered one of the major factors, which causes diabetic complications including death [3]. In diabetes, the causes and sites of intervention in biochemical process are diverse and high serum lipid profile has been implicated [4]. In the progression of diabetes, it is established that tissue damage may be due to free radicals 
attacking cell membranes through peroxidation of unsaturated fatty acids, leading to extensive damage and dysfunction of cellular membranes [5].

A numbers of reactive oxygen and non-oxygen radicals may be formed in the human body during normal cellular metabolism, and in foods in the course of production and processing [6]. These reactive radicals increase peroxidation of lipids and oxidize cellular molecules, such as proteins, lipids and DNA. These radicals also cause oxidative stress or even cell death, and impair tissues and initiate or aggravate disease processes, such as atherosclerosis, uncontrolled cellular growth, damaged lungs alveoli, emphysema, or impaired liver functions (cirrhosis), arthritis and diabetes [7, 8]. Antioxidants inhibit the oxidation of cellular molecules by blocking the chain reactions involved, and thus prevent or restore the cellular damages [9]. They exert their effects by acting as a chelator of metal catalysts, inhibiting free radicals, spurring antioxidant enzymes, plummeting $\alpha$-tocopherol radicals, and hindering oxidases [10].

The plant, $C$. odorata, is a perennial shrub belonging to the Astereaceae family, native to south and central America [11]. Although, it is considered as one of the world's worst weeds, $C$. odorata leaves and other parts have been used as folk medicine to treat a variety of ailments in tropical Africa, including malaria, dysentery, toothache, diarrhea, diabetes, skin diseases, fever and wounds [11-14]. This study aimed to investigate the antioxidant and anti-hyperglycemic properties of the extract of $C$. odorata whole roots.

\section{Materials and Methods}

Chemicals and Reagent: Randox Liquizyme assay and Spectrum diagnostic kits were used to determine the lipid profile. All chemicals and reagents were of analytical grade.

Sample preparation and extraction: Fresh whole root sample of C. odorata was collected in March 2016 at the Federal University of Technology Staff School, Minna, Niger State in Northern Nigeria. The roots were thoroughly washed under running water to remove the contaminants, were cut into pieces, dried for 2 weeks at $37^{\circ} \mathrm{C}$, and powdered, using a grinder mill. A 50g sample of the root material was extracted with $200 \mathrm{~mL}$ of methanol, using soxhlet apparatus and the resulting extract was concentrated in a rotary evaporator.
Phytochemical composition: Qualitative and quantitative phytochemical analyses were carried out on the root extract as described previously [15-17].

Determination of in vitro antioxidant activity: The antioxidant activity of the extract was determined by two in vitro methods as follow: a) using 1,1-Diphenyl2-Picrylhydrazyl (DPPH) free radical scavenging; and b) reducing power assay methods at a varying of concentrations $(2.5-100 \mu \mathrm{g} / \mathrm{mL})$, based on the method of Oyaizu [18]. All assays were carried out in triplicates and the data were subjected to statistical analyses.

Experimental animal for in vivo study: Healthy albino rats of average weight $(134.87 \pm 3.23 \mathrm{~g})$ were obtained from the animal holding unit, Federal University of Technology, Minna, Niger State, Nigeria. The rats were maintained at laboratory conditions of temperature and humidity, and at 12 hour light/dark cycles. They had free access to rat food pellets and water ad libitum. Approval to conduct this study was granted by the Committee on Ethics for Medical and Scientific Research, Federal University of Technology, Minna, Nigeria. Also, we observed the current internationally accepted principles for laboratory animal use and care as contained in the Canadian Council on Animal Care Guidelines and Protocol Review. Similarly, the study followed the Guidelines for the Care and the Use of Laboratory Animals issued by the American Commission of Life Sciences, National Research Council [19].

Experimental design: Twenty albino rats were administered a freshly prepared dose of alloxan monohydrate $(120 \mathrm{mg} / \mathrm{kg})$ intra-peritoneally. The animals had fasted overnight. The diabetic state was confirmed by testing the glucose level above $200 \mathrm{mg} / \mathrm{kg}$ bw [20]. The animals were divided into four groups and were treated with 2 $\mathrm{ml} / \mathrm{kg}$ of normal saline, $300 \mathrm{mg} / \mathrm{kg}$ or $500 \mathrm{mg} / \mathrm{kg}$ bw extract, and $5 \mathrm{mg} / \mathrm{kg}$ bw glibenclamide, respectively. All treatments were administered daily through oral route for 14 days. Five rats were also assigned as the normal control group without any treatment. The blood glucose level was monitored and the body weight taken every three days. On the $15^{\text {th }}$ day, animals in all groups were euthanized; blood samples collected and prepared to extract the serum according to the method described by previous studies $[21,22]$.

Serum lipid profile: Serum total cholesterol, triglyceride, high and low density lipoprotein cholesterol (HDL-c \& LDL-c) were estimated, using Randox diagnostic kit (United Kingdom) as described previously [23-26]. 
Statistical Analyses: Data were analyzed using Statistical Analysis System (SAS) and presented as Mean \pm SEM. Comparisons between the groups were carried out by one way analysis of variance (ANOVA) followed by Duncan's multiple range test (DMRT). The level of significance was set at $\mathrm{P}<0.05$ [27].

\section{Results}

Phytochemical Composition: The phytochemical composition of the root extract of $C$. odorata contained tannins $(54.76 \pm 4.08 \mathrm{mg} / 100 \mathrm{~g})$, saponins $(322.78 \pm 17.35$ $\mathrm{mg} / 100 \mathrm{~g})$, alkaloids $(74.34 \pm 6.08 \mathrm{mg} / 100 \mathrm{~g})$, flavonoids $(79.63 \pm 4.55 \mathrm{mg} / 100 \mathrm{~g})$, phenols $(154.32 \pm 11.21 \mathrm{mg} / 100$ $\mathrm{g})$, glycosides, steroids and reducing sugar (Table 1).

In vitro Antioxidant Activities: Figure 1 shows the effect of $C$. odorata extract on DPPH radicals. The extract exhibited dose dependent DPPH radical scavenging activity with $\mathrm{IC}_{50}$ values of $191.68 \pm 1.68 \mu \mathrm{g} / \mathrm{mL}$ compared to ascorbic acid, with the $\mathrm{IC}_{50}$ value of $45.89 \pm 0.78 \mu \mathrm{g} / \mathrm{mL}$. The extract also exhibited significant FRAP activities (Figure 2).

Hypoglycemic Effect of the Extract: The root extract of $C$. odorata at 300 and $600 \mathrm{mg} / \mathrm{kg}$ bw caused $64.15 \%$ and $68.27 \%$ hypoglycemic effects, respectively, while the standard drug (gilbenclamide) at $5 \mathrm{mg} / \mathrm{kg}$ bw caused a $71.34 \%$ hypoglycemic effect in rats.

Hypolipidemic Effect of the Extract: The effect of C. odorata root extract on the lipid profile in alloxaninduced diabetic rats is shown in Figure 3. There was a significant increase in the serum levels of total cholesterol, triglycerides and LDL levels $(\mathrm{P}<0.05)$ in diabetic untreated rats compared to those in the control group. The oral administration of the root extract caused a significant reduction in total cholesterol, triacylglycerol and LDL $(\mathrm{P}<0.05)$. Also, the HDL increased significantly to levels approaching that of the control rats.

\section{Discussion}

There has been increasing research on the role of African natural products in the treatment and clinical management of tropical and oxidative stress-related diseases $[7,28,29]$. The results presented in Table 1 indicate that $C$. odorata contained tannins $(54.76 \pm 4.08 \mathrm{mg} / 100$ g), saponins $(322.78 \pm 17.35 \mathrm{mg} / 100 \mathrm{~g})$, glycosides, alkaloids $(74.34 \pm 6.08 \mathrm{mg} / 100 \mathrm{~g})$, flavonoids $(79.63 \pm 4.55$ $\mathrm{mg} / 100 \mathrm{~g})$, phenols $(154.32 \pm 11.21 \mathrm{mg} / 100 \mathrm{~g})$, steroids and reducing sugars. This corroborated with the report of two previous studies on C. odorata root extract [30].

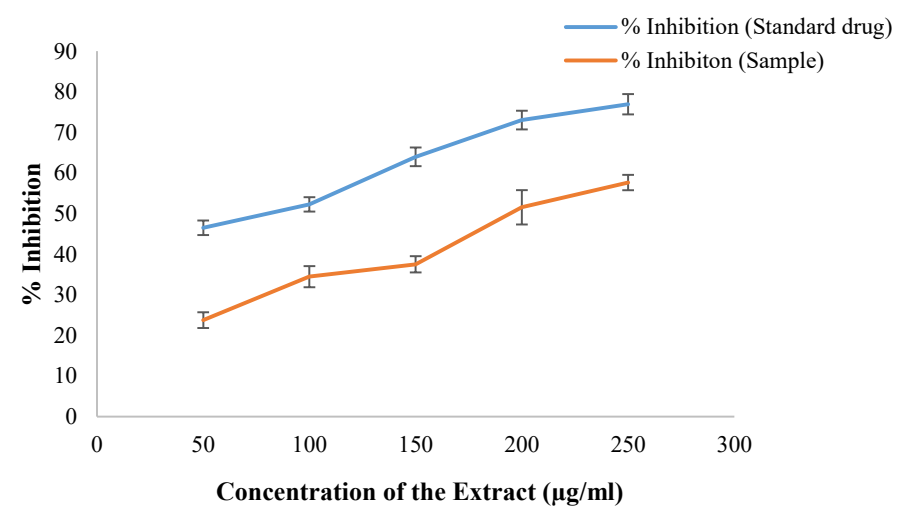

Figure 1. Free radical scavenging activity of the $C$. odorata roots extract

Table 1. Phytochemical constituents of the methanol extract of $C$. odorata root

\begin{tabular}{|c|c|c|c|}
\hline \multicolumn{2}{|c|}{ Constituent } & \multirow{2}{*}{$\begin{array}{c}\text { Inference } \\
+\end{array}$} & \multirow{2}{*}{$\begin{array}{c}\text { Composition }(\mathrm{mg} / 100 \mathrm{~g}) \\
74.34 \pm 6.08\end{array}$} \\
\hline Alkaloid & Balsams Saponins & & \\
\hline \multirow{3}{*}{ Steroid } & Flavonoids & + & $322.78 \pm 17.35$ \\
\hline & & & \\
\hline & Anthraquinone Glycoside & + & $79.63 \pm 4.55$ \\
\hline \multirow{3}{*}{ Reducing Sugar } & Tannins & + & $54.76 \pm 4.08$ \\
\hline & & & \\
\hline & Phenol & + & $154.32 \pm 11.21$ \\
\hline
\end{tabular}




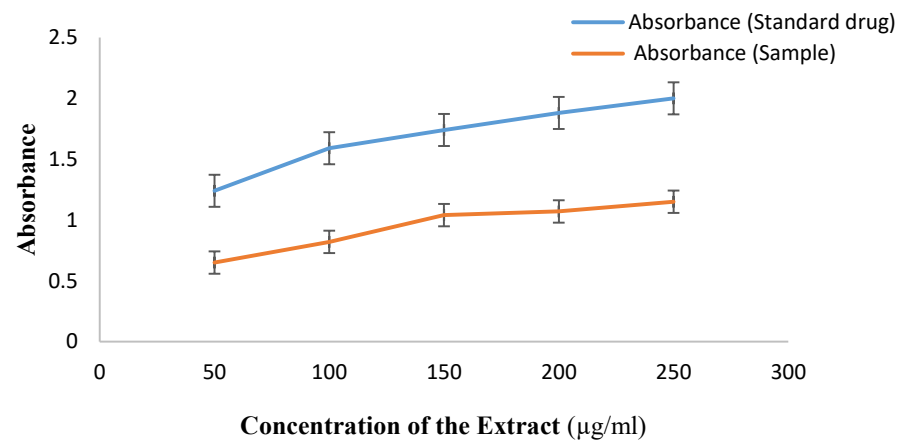

Figure 2. Ferric reducing activity of the C. odorata roots extract

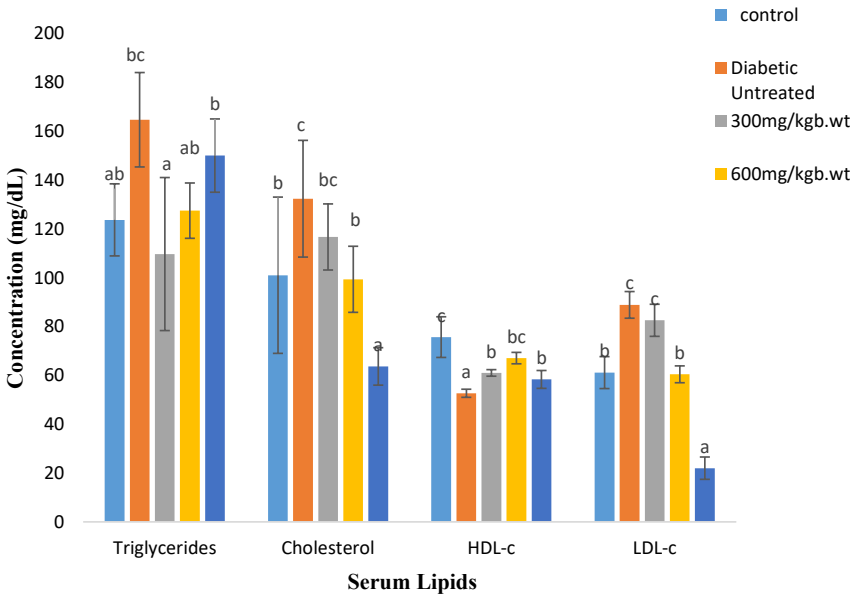

Figure 3. Effect of C. odorata extract on lipid profile

Each bar represents the mean and standard error of mean of triplicate determinations. Bars with different superscript alphabets are significantly differentfrom each other $(\mathrm{P}<0.05)$.

However, a previous study conducted by Bamisaye et al. [14] did not find alkaloids while Agaba et al. [31] did not report the presence of steroids, glycosides and reducing sugar in $C$. odorata roots. The variation in phytochemical composition of the extract could be attributed to the seasonal changes in sample collection, geographic location of the plant, and the polarity of the solvent used for the extraction process $[32,33]$.

The phenol content $(154 \pm 11.21 \mathrm{mg} / 100 \mathrm{~g})$ of $C$. odorata root extract, as reported in this study, was higher than the value $(143.3 \pm 5.14) \mathrm{mg} / 100 \mathrm{~g}$ reported by Agaba et al. [31] but lower than the level $(397.48 \pm 3.07 \mathrm{mg} / 100 \mathrm{~g})$ as reported previously for the Vernonia amygdalina (Astereceae) leaf extract [34]. Phenol has been reported to promote various physiological benefits, such as anti-tumor, antioxidant, and anti-diabetic effects. Polyphenol exerts its antidiabetic effects by regulating insulin secretion, inhibiting $\alpha$-glucosidase and enhancing antioxidant activity [6]. Flavonoids have been reported to contain anti-diabetic properties as a result of the modulatory effects on blood sugar transporters. Specifically, this is accomplished by enhancing insulin secretion, reducing apoptosis, promoting proliferation of pancreatic $\beta$-cells, reducing insulin resistance, inhibiting inflammation and oxidative stress in muscle, and promoting translocation of GLUT4 via PI3K/ AKT and AMPK pathways [10]. The alkaloids content was higher $(74.0 \pm 4.55 \mathrm{mg} / 100 \mathrm{~g})$ compared to that $(72.25 \pm 7.02$ $\mathrm{mg} / 100 \mathrm{~g}$ ) reported by Agaba et al. [31]for C. odorata leaf extract but lower than that reported for the root extract $(115.8 \pm 6.71 \mathrm{mg} / 100 \mathrm{~g})$. Alkaloids induced relatively high glucose uptake in $\beta$-TC6 and $\mathrm{C} 2 \mathrm{C} 12$ cells, showed ample antioxidant potential by alleviating $\mathrm{H}_{2} \mathrm{O}_{2}$-induced oxidative damage in $\beta$-TC6 cells, and served as "insulin sensitizer" in the management of type 2 diabetes. The mean tannins content $(54.0 \pm 4.08 \mathrm{mg} / 100 \mathrm{~g})$ was lower than the value $(145.0 \pm 11.33 \mathrm{mg} / 100 \mathrm{~g})$ reported by Agaba et al. [31] for C. odorata root extract. 
In this study, saponins were the most abundant phytochemical detected in the $C$. odorata root extract. The mean saponins value $(322 \pm 17.35 \mathrm{mg} / 10 \mathrm{~g})$ was lower than that $(348.8 \pm 15.67 \mathrm{mg} / 10 \mathrm{~g})$ reported by Agaba et al. [31]. Saponins from various plants have been reported to have hypoglycemic property. The role of saponin in the regulation of plasma glucose level and preventing diabetic complications are due to the antioxidant activity and reduction of insulin resistance in tissues, among others [10].

The protective roles of plant products against free radicals and oxidative stressors are well documented [7]. The $\mathrm{IC}_{50}$ value was negatively related to the antioxidant activity of the plant extract. This represents the amount of antioxidant needed to decrease the radical concentration by $50 \%$ [33]. In the present study, the extract exhibited a significant and dose-dependent inhibition of the DPPH activity, ranging from $23.76 \pm 1.94$ $\mu \mathrm{g} / \mathrm{ml}$ to $57.64 \pm 1.89 \mu \mathrm{g} / \mathrm{ml}$ for $50 \mu \mathrm{g} / \mathrm{ml}$ to $250 \mu \mathrm{g} / \mathrm{ml}$, respectively, of the extract (Figure 1). Our result for the $\mathrm{IC}_{50}$ value $(203 \mu \mathrm{g} / \mathrm{ml})$ was lower than that $(378 \mu \mathrm{g} / \mathrm{ml})$ reported by another study [3]. The reducing capacity of a compound may serve as an indicator of its potential antioxidant activity [9]. Our results showed that the extract promoted the transformation of $\mathrm{Fe} 3+$ to $\mathrm{Fe} 2+$ in a dose dependent manner. The phenol and flavonoid contents of the extract, as determined in this study, could be responsible for the observed free radical scavenging activity of the extract [7].

Dyslipidemia is a frequent metabolic disorder that is associated with diabetes mellitus. The hyperlipidemia is attributed to insulin-induced elevated lipolytic hormonal action on fat tissue [2]. Under normal metabolic condition, insulin activates lipoprotein lipase, which hydrolyses triacylglycerol [25]. However, in diabetes, the lipoprotein lipase is not active due to the insulin deficiency that results in hyper-triglyceridemia [25]. A number of metabolic abnormalities have been associated with the etiology of diabetic hyper-triglyceridemia and hypercholesterolemia. The decline in cholesterol and triglycerides, and increase in HDL cholesterol that were observed in this study suggest the presence of metabolites with hypolipidemic properties in the extract (Figure 3). Saponin and flavonoid contents of the extract have been associated with hypo-cholesterolemia. This effect of saponin fits with the class of direct hypoglycemic agents, as opposed to that for indirect agents, such as sulphonylurea that stimulates the release of insulin from the pancreas [25]. This finding is consistent with that of Yusufoglu et al. [2] who reported that F. duranii attenuated the plasma lipoproteins abnormalities in diabetic rats and significantly improved the levels approaching normal.

\section{Conclusions}

The methanolic root extract of $C$. odorata exhibited antioxidant, hypoglycemic and hypo-lipidemic effects. Therefore, it could be speculated that the observed hypoglycemic activity might be related to the presence of phytochemical constituents, such as flavonoids, saponins and tannins. These properties provide the extract with the potential for the therapeutic applications in patients with diabetes.

\section{Ethical Considerations}

\section{Compliance with ethical guidelines}

The principles governing the use of laboratory animals as laid out by the Federal University of Technology, Minna Committee on Ethics for Medical and Scientific Research and also existing internationally accepted principles for laboratory animal use and care as contained in the Canadian Council on Animal Care Guidelines and Protocol Review were duly observed.

\section{Funding}

The present paper was extracted from the MSc thesis of the first author, Department of Biochemistry, Federal University of Technology, Minna.

\section{Author's contributions}

All authors contributed in preparing this article.

Conflict of interest

The authors declared no conflict of interests.

\section{References}

[1] World Health Organisation. Global estimates of the prevalence of diabetes for 2017. Geneva: Diabetes WHO fact sheet; 2018. https://www.who.int/news-room/fact-sheets/detail/diabetes

[2] Yusufoglu HS, Soliman GA, Abdel-Rahman RF, AbdelKader MS, Ganaie MA, Bedir E, et al. Antihyperglycemic and antihyperlipidemic effects of Ferula duranii in experimental type 2 diabetic rats. Int J Pharmacol. 2015; 11(6):532-41. [DOI:10.3923/ijp.2015.532.541]

[3] Suresh M, Ravishankar K, Palaksha MN. Evaluation of invitro antioxidant activity of ethanolic root extract of eupatorium odoratum. World J Pharm Pharm Sci. 2014; 4(1):1009-18. https://pdfs.semanticscholar.org/fc90/ba6249e2099539d142acc806ec8af6cedb00.pdf 
[4] Aladodo RA. Effects of aqueous root extract of Jatropha curcas on hyperglycaemic and hematological indices in alloxan-induced diabetic rats. Foun J Nat Appl Sci. 2013; 2(1):52-8. http:/ / fountainjournals.com/index.php/FUJNAS/article/view/39

[5] Pandit R, Phadke A, Jagtap AG. Antidiabetic effect of Ficus religiosa extract in streptozotocin-induced diabetic rats. J Ethnopharmacol. 2010; 128(2):462-6. [DOI:10.1016/j. jep.2010.01.025] [PMID]

[6] Oboh G, Ademiluyi AO, Akinyemi AJ, Henle T, Saliu JA, Schwarzenbolz U. Inhibitory effect of polyphenol-rich extracts of jute leaf (Corchorus olitorius) on key enzyme linked to type-2 diabetes ( $a$-amylase and a-glucosidase) and hypertension (Angiotensin I converting) in vitro. J Funct Foods. 2012; 4(2):450-8. [DOI:10.1016/j.jff.2012.02.003]

[7] Lawal B, Shittu OK, Oibiokpa FI, Berinyuy EB, Mohammed H. African natural products with potential antioxidants and hepatoprotectives properties: A review. Clin Phytosci. 2017 2:23. [DOI:10.1186/s40816-016-0037-0]

[8] Tsado NA, Lawal B, Kontagora GN, Muhammad BM, Yahaya MA, Gboke JA, et al. Antioxidants and antimicrobial-activities of methanol leaf extract of Senna occidentalis. J Adv Med Pharma Sci. 2016; 8(2):1-7. [DOI:10.9734/ JAMPS/2016/25655]

[9] Lawal B, Shittu OK, Ossai PC, Abubakar AN, Ibrahim AM. Evaluation of antioxidant activity of giant African snail (Achachatina maginata) haemolymph in CCl4- induced hepatotoxixity in albino rats. Br J Pharm Res. 2015; 6(3):14154. [DOI:10.9734/BJPR/2015/15887]

[10] Moyo B, Oyedemi S, Masika PJ, Muchenje V. Polyphenolic content and antioxidant properties of Moringa oleifera leaf extracts and enzymatic activity of liver from goats supplemented with Moringa oleifera leaves/sunflower seed cake. Meat Sci. 2012; 91(4):441-7. [DOI:10.1016/j.meatsci.2012.02.029] [PMID]

[11] Akinmoladun A, Akinloye O. Effect of Chromolaena odorata on hypercholesterolemia-related metabolic imbalances. In: Onibi GE. Proceedings of the Akure-Humboldt Kellogg/3rd SAAT Annual Conference Federal University of Technology, Akure Nigeria, 16-19 April, 2007. Akure: Federal University of Technology/School of Agriculture and Agricultural Technology; 2007. p. 287-90. https://books.google. com/books?id=mNoJAQAAMAAJ\&dq

[12] Phan TT, Wang L, See P, Grayer RJ, Chan SY, Lee ST. Phenolic compounds of Chromolaena odorata protect cultured skin cells from oxidative damage: Implication for $\mathrm{cu}-$ taneous wound healing. Biol Pharm Bull. 2001; 24(12):1373-9. [DOI:10.1248/bpb.24.1373] [PMID]

[13] Zachariades C, Day M, Muniappan R, Reddy GVP. Chromolaena odorata (L.) King and Robinson (Asteraceae). Muniappan R, Reddy GVP, Raman A, editors. Biological Control of Tropical Weeds Using Arthropods. Cambridge, UK: Cambridge University Press; 2009. 130-62. [DOI:10.1017/ CBO9780511576348.008]

[14] Bamisaye FA, Ajani EO, Nurain IO, Minari JB. Medicobotanical investigation of siam weed (Chromolaena odorata)) used among the "Ijebu" people of Ogun State, Nigeria. J Med Med Sci. 2014; 5(1):20-4.

[15] AOAC International, Horwitiz W. Official methods of analysis of AOAC international. Horwitiz W, editor. $18^{\text {th }}$ ed. Rockville: AOAC International; 2005.
[16] Oloyede OI. Chemical profile of unripe pulp of Carica papaya. Pak J Nutr. 2005; 4(6):379-81. [DOI:10.3923/ pjn.2005.379.381]

[17] Sofowara A. Medicinal plants and traditional medicine in Africa. Ibadan: Spectrum Books; 1993.

[18] Oyaizu M. [Studies on products of browning reactions: Antioxidative activities of products of browning reaction prepared from glucosamine (Japanese)]. Jpn J Nutr Diet. 1986; 44(6):307-15. [DOI:10.5264/eiyogakuzashi.44.307]

[19] National Research Council, Commission on Life Sciences, Institute for Laboratory Animal Research, Committee on Occupational Safety and Health in Research Animal Facilities. Occupational health and safety in the care and use of research animals. Washington DC: National Academies Press; 1997.

[20] Etuk EU. Animals models for studying diabetes mellitus. Agric Biol J. 2010; 1(2):130-4.

[21] Bashir L, Shittu OK, Busari MB, Sani S, Aisha MI. Safety evaluation of giant African land snails (Archachatina marginata) haemolymph on hematological and biochemical parameters of Albino rats. J Adv Med Pharm Sci. 2015; 3(3):122-30. [DOI:10.9734/JAMPS/2015/16393]

[22] Amos TN, Bashir L, Saba SE, Saba MA, Mohammed BM Abdulsalam IH, et al. Phytochemicals and acute toxicity profile of aqueous and methanolic extracts of Crateva adansonii leaves in Swiss albino rats. Asian J Biochem. 2015; 10(4):173-9. [DOI:10.3923/ajb.2015.173.179]

[23] Robinson D, Ferns GA, Bevan EA, Stocks J, Williams PT, Galton DJ. High density lipoprotein subfractions and coronary risk factors in normal men. Arteriosclerosis. 1987; 7(4):341-6. [DOI:10.1161/01.ATV.7.4.341] [PMID]

[24] Phalak P, Tilak M. Study of lipid profile in pre-eclampsia. Indian J Basic Appl Med Res. 2012; 2(5):405-9.

[25] Assmann G, Schriewer H, Schopohl B, Funke H. Investigation of the specificity of the HDL-cholesterol test. In: Greten H, Lang PD, Schettler G, editors. Lipoproteins and Coronary Heart Disease: New Aspects in the Diagnosis and Therapy of Disorders of Lipid Metabolism: International Symposium, Vienna, May 12-13, 1979. Baden-Baden: Witzstrock; 1980. p. 43-5.

[26] Friedewald WT, Levy RI, Fredrickson DS. Estimation of the concentration of low-density lipoprotein cholesterol in plasma without use of the preparative ultracentrifuge. Clin Chem. 1972; 18(6):499-502. [DOI:10.1093/clinchem/18.6.499] [PMID]

[27] Statistical Analysis System (SAS). Institute, S.A.S. and S.A.S. Publishing, SAS/STAT 9.2 User's Guide: The GLM Procedure (Book Excerpt). IT Pro. Inc.; 2008. https://books. google.com.tw $/$ books?id=DvhxtAEACAAJ

[28] Lawal B, Shittu OK, Kabiru AY, Jigam AA, Umar MB, Berinyuy EB, et al. Potential antimalarials from African natural products: A review. J Intercult Ethnopharmacol. 2015; 4(4):318-43. [DOI:10.5455/jice.20150928102856] [PMID] [PMCID]

[29] Bashir L, Shittu OK, Sani S, Busari MB, Adeniyi KA. African natural products with potential anti-trypanosoma properties: A review. Int J Biochem Res Rev. 2013; 7(2):45-79. [DOI:10.9734/IJBCRR/2015/16039]

[30] Nanadini N, Nagababu P, Umamaheswara Rao V, Venugopal N. Phytochemical antimicrobial and antioxidant prop- 
erties of an invasive weed - Chromolaena odorata (L.) King \& Robinson. Int J Phytomed. 2014; 6(2):286-92.

[31] Agaba TA, Fawole B. Phytochemical constituents of siam weed (Chromolaena odorata) and African custard apple (Annona senegalensis). Int J Food Agric Vet. 2014; 6(1):35-42.

[32] Lawal B, Ossai PC, Shittu OK, Abubakar AN. Evaluation of phytochemicals, proximate, minerals and anti-nutritional compositions of yam peel, maize chaff and bean coat. Int J Appl Biol Res. 2014; 6(2):21-37.

[33] Ndarubu TA, Bashir L, Chukwudi OP, Aliyu J, Kontagora GN, Gboke JA, et al. Antioxidants and antimicrobial activities of methanol extract of Newbouldia laevis and Crateva adansonii. J Pharm Allied Health Sci. 2016; 6(1-2):14-9. [DOI:10.3923/jpahs.2016.14.19]

[34] Akah PA, Alemji JA, Salawu OA, Okoye TC, Offiah NV. Effects of Vernonia amygdalina on biochemical and hematological parameters in diabetic rats. Asian J Med Sci. 2009; 1(3):108-13. 
This Page Intentionally Left Blank 